\title{
IDENTIFIKASI MORFOLOGI DAN MORFOMETRI ORGANPENCERNAANSERTA SIFAT KUALITATIF WARNA BULU BELIBIS KEMBANG (Dendrocygna arcuata) DAN BELIBIS BATU (Dendrocygna javanica)
}

\author{
Identification of Morphology and Viscera Morphometry and Qualitative Traitof Feather \\ Color Wandering Whisling Duck (Dendrocygna arcuata)and Lesser Whistling Duck \\ (Dendrocygna javanica)
}

\author{
Nugraha Siwi ${ }^{1}$, Tri Hesti Wahyuni ${ }^{2}$ dan Hamdan ${ }^{2}$ \\ 1. Mahasiswa Program Studi Peternakan Fakultas Pertanian Universitas Sumatera Utara \\ 2. Staf Pengajar Program Studi Peternakan Fakultas Pertanian Universitas Sumatera Utara
}

\begin{abstract}
Identification of morphology, morphometric and the qualitative trait feather color is the basis of a selection process and breeding whistling duck. This research aims to identify the main identifier on size and shape as well the qualitative nature of wandering (Dendrocygna arcuata) and lesser whistling duck (Dendrocygnajavanica). The number of samples were studied was 10 head for each species. Data were analyzed using Principal Component Analysis with Software Statistical Package of Social Science, SPSS. The results showed that primary identifier size morphology for wandering and lesser whistling duck was length of wing and tibia, while the identifier shape morphology was third finger length and wing. The main identifier size of viscera morphometry was small intestine, while the main identifier shape on large intestine for both. The main identifier size and shape of organs digestive tract is weight liver and ventricle, while the primary identifier shape is weight digestive organs are liver and small intestine weight. The different for qualitative trait of feather color in wandering whistling duck has a thick black line from the head to neck and a thick white feather color on the back of the body to the tail, whilelesser whistling duck has a striking maroon red color on chest feathers. Conclusion, the morphology and Viscera morphometry for wanderingis larger than lesser whistling duck.
\end{abstract}

Keywords : Wandering whistling duck, Lesser whistling duck, Morphology, Morphometric, Qualitative trait.

\begin{abstract}
ABSTRAK
Identifikasi terhadap morfologi, morfometri dan sifat kualitatif warna bulu merupakan dasar dari beberapa proses seleksi dan pemuliaan burung belibis. Tujuan penelitian ini untuk mengidentifikasi penciri utama ukuran dan bentuk serta sifat kualitatif warna bulu belibis kembang (Dendrocygna arcuata) dan belibis batu (Dendrocygna javanica).Sampel yang diteliti sebanyak 10 ekor setiap species. Data dianalisis menggunakan Analisis Komponen Utama dengan bantuan Software Statistical Package Sosial Science, SPSS. Hasil penelitian menunjukkan bahwa penciri utama ukuran morflogi belibis kembang dan belibis batu adalah panjang sayap dan panjang tibia, sedangkan penciri bentuk morfologi adalah panjang jari ketiga dan panjang sayap. Penciri utama ukuran panjang organ saluran pencernaan adalah panjang usus kecil, sedangkan penciri utama bentuk adalah panjang usus besar untuk keduanya. Penciri utama ukuran dan bentuk pada berat organ saluran pencernaan adalah berat hati dan berat ventrikulus, sedangkan penciri utama bentuk pada berat organ pencernaan adalah berat hati dan berat usus kecil perbedaan pada sifat kualitatif warna bulu pada belibis kembang memiliki garis hitam tebal dari atas kepala sampai leher dan warna bulu putih yang tebal pada bagian tubuh belakang sampai ekor, belibis batu memiliki warna merah maroon mencolok pada bulu bagian dada. Kesimpulan, morfologi dan morfometri organ pencernaan belibis kembang lebih besar dari belibis batu.
\end{abstract}

Kata kunci : Belibis kembang, belibis batu, morfologi, morfometrik, sifat kualitatif. 


\section{PENDAHULUAN}

Pertambahan penduduk yang semakin pesat di Indonesia dewasa ini menyebabkan semakin meningkatnya kebutuhan konsumsi dan selera dalam makanan, ini mengakibatkan munculnya ide-ide dalam menghidangkan makanan termasuk dari unggas.Unggas merupakan salah satu penghasil protein hewani yang baik untuk di konsumsi masyarakat.

Ternak unggas yang telah didomestikasi dapat dibedakan menjadi dua yaitu unggas air dan unggas darat berdasarkan bentuk cakarnya. Cakar pada unggas darat berbentuk jarijari yang terpisah, sedangkan pada unggas air memiliki selaput renang yang menghubungkan jari-jarinya.

Kontribusi ternak unggas terhadap penyediaan daging sebesar 1.335 .143 ton atau $64,46 \%$ dari jumlah total daging nasional. Kebutuhan daging sebagai sumber protein menjadi meningkat,sehingga perlu dilakukan terobosan pencarian hewan satwa liar yang mempunyai potensi sebagai alternatif penghasil daging (Semarang Bird Web, 2009). Eksplorasi dan pemburuan hewan liar dapat dijadikan sumber pangan, untuk menambah penghasilkan dan memenuhi kebutuhan protein hewani, sehingga perlu dilakukan pelestariannya berupa penangkaran dan budidaya jenis-jenis hewan tertentu (Hardjosubroto, 1994). Pemanfaatan jenis-jenis hewan liar yang dianggap langka saat ini, dapat dilakukan dengan usaha peternakan yang berpedoman pada prinsip-prinsip pelestarian.

Burung belibis adalah salah satu burung yang memiliki habitat lebih dekat di air, kemampuannya yang dapat berenang di air disebabkan karena burung belibis termasuk burung yang memiliki kaki berselaput dan jarang untuk melakukan terbang. Aktivitas mobilitas di daerah teresterial, hanya digunakan untuk mencari makan dan menghindari lawan, bertelur dan aktivitas lainnya.Pergerakan berjalan sangat lambat, namun sangat cepat saat berada di air, sehingga dalam mobilitas dari hewan ini sangat kecil untuk daerah teresterial.

Indonesia memiliki beberapa tempat untuk hidup burung belibis. Belibis kembang (Dendrocygna arcuata) dan belibis batu (Dendrocygna javanica) merupakan jenis belibis yang hidup di Indonesia dan mempunyai prospek yang bagus untuk dikembangkan, daerah persinggahan burung belibis ini berada di pulau Kalimantan, pulau Sumatera dan pulau Jawa. Masyarakat di Kalimantan sudah lama mengkonsumsi belibis sebagai makanan dan peredaran penjualan belibis di pulau tersebut mulai diawasi karena masyarakat masih sedikit melakukan pengembangbiakkan sedangkan pemburu liar masih menangkapi langsung dari alam tanpa ada pengawasan.Berdasarkan data tahun 2006, jumlah belibis yang ditangkap di danau 
Mahakam Kalimantan Timur pada tahun 2004 berkisar antara 120.000-165.000 ekor dan dari jumlah tersebut sekitar 95\% atau sebanyak 114.000 - 156.000 ekor dipasarkan di Banjarmasin (Darmawan, 2011). Eksistensi dan potensi hewan ini belum banyak terungkap, walaupun sebagian besar masyarakat telah mengenalnya sebagai itik liar Indonesia tercatat sebanyak 15 macam, dua di antaranya mempunyai prospek yang baik untuk dikembangkan, yaitu belibis batu dan belibis kembang (Wikipedia, 2007).

Penelitian dengan judul Morfologi dan Morfometri Organ Pencernaan serta Sifat Kualitatif Belibis Kembang dan Belibis Batu ini merupakan salah satu dasar tujuan untuk mengetahui kemampuan burung belibis dalam memenuhi konsumsi masyarakat akan daging unggas yang ada di Indonesia.

\section{BAHAN DAN METODE PENELITIAN}

\section{Tempat dan Lokasi Penelitian}

Pelaksanakan penelitian ini dilaksanakan pada Agustus 2012 bulan sampai Februari 2013. Pengambilan data dan pembedahan di Laboratorium Anatomi dan Fisiologi ternak Fakultas Pertanian Universitas Sumatera Utara, sampel didapatkan dari beberapa tempat di Sumatera Utara, mulai dari rumah makan burung, penjual di pinggir jalan dan pemburu khusus pengambilan sampel di Kota Datar Langkat, Pantai Labu Deli Serdang dan rumah makan belibis yang berada di daerah jalan Binjai Km 13,2.

\section{Bahan dan Alat Penelitian}

Bahan dari penelitian ini adalah Belibis kembang sebanyak 5 ekor jantan 5 ekor betina, dan belibis batu sebanyak 5 ekor jantan dan 5 ekor betina sebagai objek penelitian. Alat yang dipergunakan yaitu jangka sorong dan pita ukur sebagai alat pengukur.Kamera sebagai alat dokumentasi. Timbangan sebagai alat pengukur berat. Pisau sebagai alat untuk memotong dan membedah.

\section{Metode Penelitian}

Metode penelitian yang digunakan adalah metode deskriptif. Setiap ukuran tubuh luar dan organ dalam serta beberapa sifat kualitatif diukur dan diamati untuk pengambilan data. Pencatatan data meliputi ukuran tubuh luar dan organ dalam serta sifat kualitatif yang ada pada belibis jantan dan betina secara deskriptif. 


\section{Pengumpulan Data}

Organ tubuh luar yang diukur adalah panjang tarsometatarsus, keliling tarsometatarsus, panjang tibia, panjang femur, panjang sayap, panjang jari ketiga dan panjang maxilla (Tzeng et al, 2000). Organ dalam saluran pencernaan yang diukur adalah panjang paruh, panjang oesophagus, panjang ventrikulus, panjang usus kecil dan panjang usus besar (Srigandono, 1986), sedangkan organ dalam saluran pencernaan yang diukur dengan berat adalah berat oesophagus, berat tembolok, berat ventrikullus berat usus kecil, berat usus besar, berat kloaka dan berat hati (Parera , 1991)

\section{a. Panjang Tarsometatarsus}

Panjang tulang tarsometatarsus diwakili oleh sebuah tulang yang dibentuk persatuan metatarsal yang kedua, ketiga dan keempat.Pengukuran tulang tarsometatarsus dengan menggunakan jangka sorong.

\section{b. Keliling Tarsometatarsus}

Keliling tulang tarsometatarsus diukur dengan menggunakan pita ukur pada bagian tengah tulang tarsometatarsus.Dilakukan pada tepat di bagian tengah tulang tarosmetatarsus dengan mengukur panjangnya terlebih dahulu dan mengambil garis tengah untuk mengukur keliling tulang tarsometatarsus.

\section{c. Panjang Tibia}

Pengukuran tibia dilakukan dari patella samapai ujung tibia dengan menggunakan jangka sorong.Bagian lateral tibia berkaitan dengan fibula dan bagian proximal berkaitan dengan tulang femur.

\section{d. Panjang Femur}

Tulang femur terletak diatas tulang persendian patella dengan bentuk yang agak melengkung.Pengukuran dilakukan pada femur menggunakan jangka sorong dengan meraba ujung bagian pangkal atas dan ujung pangkal bawah tulang femur.

\section{e. Panjang Sayap}

Pengukuran panjang sayap dilakukan dengan jangka sorong.Pengukuran dilakukan dari ujung tulang sayap yang terkait dengan tulang belakang sampai ujung tulang sayap phalanges.

\section{f. Panjang Jari Ketiga}

Pengukuran jari ketiga dilakukan hanya pada jari terpanjang dari empat buah tulang phalanges yang ada pada tulang jari.Pengukuran pada jari terpanjang dilakukan dengan menggunakan jangka sorong. 


\section{g. Panjang Maxilla}

Panjang maxilla adalah panjang dari paruh bagian atas pada unggas dengan pengukuran menggunakan jangka sorong.Panjang maxilla lebih pendek dari panjang mandibula pada belibis.

\section{h. Panjang Paruh}

Panjang paruh yang diukur pada penelitian ini adalah panjang dari paruh bagian bawah (mandibulla) yang menggunakan jangka sorong dalam pengukuran.

\section{i. Panjang dan Berat Oesophagus}

Oesophagus diukur dengan menggunkan meteran atau pita ukur.Oesophagus diukur dari ujung pangkal yang bertemu mulut sampai gizard.

\section{j. Panjang dan Berat Proventrikullus}

Pengukuran pada Proventrikullus dilakukan dengan menghitung panjang dan beratnya.Panjang diukur dengan pita ukur dan berat ditimbang dengan timbangan diagram.

\section{k. Berat Tembolok}

Tembolok yang ada di timbang dengan timbangan diagram.Diambil dari bagian leher pada belibis di dekat saluran kerongkongan (oesophagus).

\section{Berat Ventrikulus}

Berat ventrikulus dipisahkan dengan bagian proventrikulus dengan memotong di ujung bagian pangkal antara pertemuan ventrikulus dengan proventrikulus.Ventrikulus hanya diukur beratnya saja karena tidak ada bentuk ventrikulus tidak mengindikasikan untuk mengukur panjangnya.

\section{m. Panjang dan Berat Usus Kecil}

Usus kecil dipotong kemudian diukur dari bagian pangakal yang mencakup duodenum, jejunum dan ileum dengan pita ukur.Berat seluruh usus kecil diukur dengan timbangan diagram.

\section{n. Panjang dan Berat Usus Besar}

Pangkal usus besar diukur dari ujung sekum sampai ujung yang bersambung ke rectum dan panjangnya diukur dengan menggunakan pita ukur.Berat usus besar diukur dengan timbangan diagram.

\section{o. Berat Kloaka}

Kloaka haya diukur dengan timbangan diagram untuk diambil data beratnya karena kloaka tidak menunjukkan bentuk yang simetris untuk diukur dengan satuan panjang. 


\section{p. Berat Hati}

Bagian hati diambil sebagai bagian asesoris yang diukur dengan timbangan diagram. Hati merupakan organ asesoris mencakup dalam saluran pencernaan yang berfungsi sebagai penetral racun untuk membantu pada organ saluran pencernaan.

\section{Parameter Penelitian}

Parameter yang dilakukan dalam penelitian ini adalah:

1. Morfologi organ tubuh luar (panjang tarsometatarsus),keliling tarso metatarsus, panjang tibia, panjang femur, panjang sayap, panjang jari ketiga, panjang maxilla).

2. Organ pencernaan (paruh, oesophagus, crop, proventrikulus, ventikulus, usus kecil, usus besar,kloaka dan hati).

3. Sifat kualitatif warna bulu.

\section{Analisis Data}

Data yang diperoleh awalnya dihitung nilai rataan, standart devisiasi (SD), dan koefisien keragaman (KK) dari setiapa peubah yang diamati dengan menggunakan SPSS 18. Sedangkan data ukuran tubuh belibis yang sudah dianalisis dengan SPSS 18 kemudian diolah lagi dengan menggunakan Analisis Komponen Utama (AKU) (Nishidaet al, 1982). Pengolahan data dengan menggunakan AKU dilakukan berdasarkan pengelompokan berdasarkan jenis kelamin dari belibis dengan model matematika sebagai berikut (Gaspersz, 1992):

$Y_{p}=a_{1 p} X_{1}+a_{2 p} X_{2}+a_{3 p} X_{3}+a_{4 p} X_{4}+\ldots .+a_{n p} X_{n}$

Keterangan:

$\mathrm{Y}_{\mathrm{p}} \quad=$ komponen utama ke-p

$\mathrm{a}_{1 \mathrm{p}}, \mathrm{a}_{2 \mathrm{p}}, \ldots \mathrm{a}_{\mathrm{np}}=$ vektor ciri/vektor Eigen ke-1,..., $\mathrm{n}$ pada komponen utama ke-p

$\mathrm{X}_{1}, \mathrm{X}_{2}, \ldots, \mathrm{X}_{\mathrm{n}}=$ peubah-peubah yang diamati yaitu : (panjang tarsometatarsus, keliling tarsometarsus, panjang tibia, panjang femur, panjang sayap,panjang jari ketigapanjang maxilla).

Model matematika yang digunakan untuk menganalisis morfometrik organ dalam adalah sebagai berikut:

$$
Y_{p}=a_{1 p} X_{1}+a_{2 p} X_{2}+a_{3 p} X_{3}+a_{4 p} X_{4}+\ldots .+a_{n p} X_{n}
$$


Keterangan :

$\mathrm{Y}_{\mathrm{p}} \quad=$ komponen utama ke-p

$\mathrm{a}_{1 \mathrm{p}}, \mathrm{a}_{2 \mathrm{p}}, \ldots \mathrm{a}_{\mathrm{np}}=$ vektor ciri/vektor Eigen ke-1,..., $\mathrm{n}$ pada komponen utama ke-p peubahpeubah yang diamati, yaitu:

Organ pencernaan (organ - organ pencernaan terdiri dari: paruh, oesophagus, crop, proventrikulus, ventrikulus, usus halus, usus besar dan kloaka) dan organ asesories yang terdiri dari hati, sedangkan untuk melihat sifat kualitatif warna bulu pada belibis inidigunakan rumus frekuensi relative (Fr). Persamaannya adalah:

$$
\text { Fr }=\stackrel{x}{-} \times 100 \%
$$

Keterangan:

Fr $\quad=$ frekuensi relative $\%$

$\mathrm{X} \quad=$ jumlah sampel dengan warna tertentu (ekor)

$\mathrm{n} \quad=$ jumlah keseluruhan (ekor)

\section{HASIL DAN PEMBAHASAN}

\section{Ukuran-ukuran linear pada Belibis Kembang (Dendrocygna arcuata)}

Data diolah dengan menggunakan program SPSS 18. Pengukuran organ tubuh bagian luar dilakukan kepada 10 ekor belibis kembang (Dendrocygna arcuata) yaitu masing-masing 5 ekor belibis kembang jantan dan 5 ekor belibis kembang betina.Beberapa bagian tubuh bagian luar menunjukkan hasil yang berbeda tidak jauh dari perbandingan antara belibis kembang jantan dan belibis kembang betina. Ukuran-ukuran tubuh luar belibis kembang dapat dilihat pada Tabel 1.

Berdasarkan Tabel 1 dapat dilihat perbedaan ukuran-ukuran linear organ tubuh bagian luar dari belibis kembang. Koefisien keragaman terendah organ luar belibis kembang jantan terletak pada panjang jari ketiga yaitu 1,08\% dan koefisien keragaman tertinggi terletak pada keliling tarsometatarsus yaitu $5,45 \%$. Koefisien keragaman terendah pada belibis kembang betina terletak pada panjang sayap yaitu $1,2 \%$ dan koefisien keragaman tertinggi terletak pada keliling tarsometatarsus yaitu 6,04\%. Hal ini menunjukkan kesamaan dari koefisien keragaman tertinggi dari organ tubuh luarbelibis kembang antara jantan dan betina yaitu pada keliling tarsometatarsus. Ukuran panjang organ pencernaan juga memperlihatkan perbedaan antara jantan dan betina, perbedaan tersebut dapat dilihat dari ukuran panjang organ dalam saluran pencernaan (Frandson ,1992). Perbedaan ukuran panjang organ pencernaan belibis kembang dapat dilihat dari Tabel 2. 
Tabel 1.Ukuran-ukuran linear organ luar belibis kembang(cm)

\begin{tabular}{lcccc}
\hline Variabel & \multicolumn{2}{c}{$\begin{array}{c}\text { Jantan } \\
\text { (n=5 ekor })\end{array}$} & \multicolumn{2}{c}{$\begin{array}{c}\text { Betina } \\
(\mathrm{n}=5 \text { ekor })\end{array}$} \\
\cline { 2 - 5 } & $\begin{array}{c}\text { Hasil } \\
\text { pengukuran }\end{array}$ & KK $(\%)$ & $\begin{array}{c}\text { Hasil } \\
\text { pengukuran }\end{array}$ & KK (\%) \\
\hline $\begin{array}{l}\text { Panjang } \\
\text { Tarsometatarsus }\left(\mathrm{X}_{1}\right)\end{array}$ & $6,28 \pm 0,25$ & 3,96 & $5,92 \pm 0,13$ & 2,20 \\
$\begin{array}{l}\text { Keliling } \\
\text { Tarsometatarsus }\left(\mathrm{X}_{2}\right)\end{array}$ & $2,9 \pm 0,15$ & 5,45 & $2,72 \pm 0,16$ & 6,04 \\
Panjang tibia $\left(\mathrm{X}_{3}\right)$ & $8,94 \pm 0,28$ & 3,22 & $8,58 \pm 0,27$ & 2,66 \\
Panjang femur $\left(\mathrm{X}_{4}\right)$ & $5,14 \pm 0,18$ & 3,53 & $4,58 \pm 0,17$ & 3,42 \\
Panjang sayap $\left(\mathrm{X}_{5}\right)$ & $15,92 \pm 0,35$ & 2,19 & $15,69 \pm 0,35$ & 1,2 \\
Panjang & $6,04 \pm 0,09$ & 1,08 & $5,6 \pm 0,15$ & 2,82 \\
jari ketiga $\left(\mathrm{X}_{6}\right)$ & $4,39 \pm 0,14$ & 3,26 & $4,2 \pm 0,08$ & 1,88 \\
Panjang maxilla $\left(\mathrm{X}_{7}\right)$ & & & & \\
\hline
\end{tabular}

Ket : $\mathrm{X}=$ Rataan, $\mathrm{SD}=$ Standart Devisiasi, $\mathrm{KK}=$ Koefisien Keragaman, $\mathrm{n}=$ Jumlah sampel

Tabel 2. Ukuran panjang organ saluran pencernaan belibis kembang (cm)

\begin{tabular}{|c|c|c|c|c|}
\hline \multirow[t]{2}{*}{ Variabel } & \multicolumn{2}{|c|}{$\begin{array}{c}\text { Jantan } \\
(\mathrm{n}=5 \text { ekor })\end{array}$} & \multicolumn{2}{|c|}{$\begin{array}{c}\text { Betina } \\
(\mathrm{n}=5 \text { ekor })\end{array}$} \\
\hline & $\begin{array}{c}\text { Hasil } \\
\text { pengukuran }\end{array}$ & KK $(\%)$ & $\begin{array}{c}\text { Hasil } \\
\text { pengukuran }\end{array}$ & $\mathrm{KK}(\%)$ \\
\hline Paruh $\left(\mathrm{X}_{1}\right)$ & $4,22 \pm 0,14$ & 3,53 & $3,94 \pm 0,17$ & 4,47 \\
\hline Panjang Oesophagus $\left(\mathrm{X}_{2}\right)$ & $4,25 \pm 0,13$ & 3,08 & $4,6 \pm 0,106$ & 2,32 \\
\hline Panjang Proventrikulus $\left(\mathrm{X}_{3}\right)$ & $5,28 \pm 0,22$ & 4,31 & $5,12 \pm 0,207$ & 4,06 \\
\hline Panjang Usus Kecil $\left(\mathrm{X}_{4}\right)$ & $28,4 \pm 1,04$ & 3,69 & $27,66 \pm 1,23$ & 4,46 \\
\hline Panjang Usus Besar $\left(\mathrm{X}_{5}\right)$ & $7,6 \pm 0,23$ & 2,89 & $7,6 \pm 0,16$ & 2,23 \\
\hline
\end{tabular}

Ket $\overline{\bar{X}}=$ Rataan, $\mathrm{SD}=$ Standart devisiasi, $\mathrm{KK}=$ Koefisien Keragaman , $\mathrm{n}=$ Jumlah sampel

Ukuran keragaman tertinggi terdapat pada panjang proventrikulus yaitu $4,31 \%$, sedangkan pada belibis kembang betina koefisien keragaman terendah juga terdapat pada panjang usus besar yaitu 2,23\% dan keragaman tertinggi terdapat pada panjang paruh yaitu 4,47\% ini menunjukkan kesamaan koefisien keragaman terendah pada panjang organ pencernaan belibis kembang jantan dan belibis kembang betina memiliki kesamaan di koefisien terendah yaitu pada panjang usus besar.

Beberapa organ pencernaan yang tidak dapat diukur dengan satuan panjang $(\mathrm{cm})$. Organ dalam saluran pencernan juga memiliki berat masing-masing yang dapat membedakan 
ukuran dan bentuk, perbedaan berat masing-masing organ dalam saluran pencernaan dapat dilihat pada Tabel 3 di bawah ini.

Tabel 3. Ukuran berat organ saluran pencernaan belibis kembang (g)

\begin{tabular}{|c|c|c|c|c|}
\hline \multirow{2}{*}{ Variabel } & \multirow{2}{*}{$\begin{array}{c}\begin{array}{c}\text { Jantan } \\
(\mathrm{n}=5 \text { ekor })\end{array} \\
\begin{array}{c}\text { Hasil } \\
\text { pengukuran }\end{array}\end{array}$} & \multicolumn{3}{|c|}{$\begin{array}{c}\text { Betina } \\
(\mathrm{n}=5 \text { ekor })\end{array}$} \\
\hline & & KK $(\%)$ & $\begin{array}{c}\text { Hasil } \\
\text { pengukuran }\end{array}$ & KK $(\%)$ \\
\hline Berat Oesophagus $\left(\mathrm{X}_{1}\right)$ & $1,56 \pm 0,11$ & 7,3 & $1,58 \pm 0,09$ & 5,78 \\
\hline Berat Tembolok $\left(\mathrm{X}_{2}\right)$ & $0,268 \pm 0,03$ & 13,03 & $0,286 \pm 0,02$ & 8,42 \\
\hline Berat Proventrikulus $\left(\mathrm{X}_{3}\right)$ & $0,96 \pm 0,04$ & 4,49 & $0,896 \pm 0,27$ & 3,01 \\
\hline Berat Ventrikulus $\left(\mathrm{X}_{4}\right)$ & $19,2 \pm 0,43$ & 2,25 & $18,73 \pm 0,31$ & 1,69 \\
\hline Berat Usus Kecil $\left(\mathrm{X}_{5}\right)$ & $5,2 \pm 0,22$ & 4,30 & $4,92 \pm 0,248$ & 5,06 \\
\hline Berat Usus Besar $\left(\mathrm{X}_{6}\right)$ & $3,52 \pm 0,25$ & 7,35 & $3,3 \pm 0,21$ & 6,42 \\
\hline Berat Kloaka $\left(\mathrm{X}_{7}\right)$ & $1,81 \pm 0,04$ & 2,62 & $1,808 \pm 0,026$ & 1,48 \\
\hline Berat Hati $\left(\mathrm{X}_{8}\right)$ & $10,65 \pm 0,50$ & 4,75 & $10,14 \pm 0,32$ & 3,24 \\
\hline
\end{tabular}

Koefisien keragaman terendah pada organ pencernaan yang diukur dengan satuan panjang (cm) belibis kembang jantan terdapat pada panjang usus besar yaitu 2,89\% . Koefisien keragaman organ pencernaan yang di hitung dari beratnya pada belibis kembang jantan dan belibis kembang betina menunjukkan koefisien keragaman terendah yang sama pada berat kloaka yaitu, 2,62\% sedangkan pada belibis kembang betina yaitu, 1,48\% dan koefisien keragaman tertinggi juga menunjukkan hasil keragaman yang sama pada belibis kembang jantan dan betina yang terdapat pada berat tembolok. Pada belibis kembang jantan yaitu, 13,03\%dan pada belibis kembang betina yaitu, 8,42\% ini menunjukkan bahwa terdapat kesamaan pada koefisien keragaman berat organ dalam saluran pencernaan belibis kembang.

\section{Ukuran-ukuran linear pada Belibis Batu (Dendrocygna javanica)}

Pengukuran organ tubuh bagian luar dilakukan kepada 10 ekor belibis batu (Dendrocygna javanica) yaitu masing-masing 5 ekor belibis batu jantan dan 5 ekor belibis batu betina.Beberapa bagian tubuh bagian luar menunjukkan hasil yang berbeda tidak jauh dari perbandingan antara belibis batu jantan dan belibis batu betina.Ukuran-ukuran tubuh luar belibis batu dapat dilihat pada Tabel 4 di bawah ini. 
Tabel 4. Ukuran linear organ tubuh luar belibis batu $(\mathrm{cm})$

\begin{tabular}{|c|c|c|c|c|}
\hline \multirow[t]{2}{*}{ Variabel } & \multicolumn{2}{|c|}{$\begin{array}{c}\text { Jantan } \\
(\mathrm{n}=5 \text { ekor }) \\
\end{array}$} & \multicolumn{2}{|c|}{$\begin{array}{c}\text { Betina } \\
(\mathrm{n}=5 \text { ekor })\end{array}$} \\
\hline & $\begin{array}{c}\text { Hasil } \\
\text { pengukuran }\end{array}$ & $\begin{array}{l}\mathrm{KK} \\
(\%)\end{array}$ & $\begin{array}{c}\text { Hasil } \\
\text { pengukuran }\end{array}$ & $\begin{array}{l}\mathrm{KK} \\
(\%)\end{array}$ \\
\hline $\begin{array}{l}\text { Panjang } \\
\text { Tarsometatarsus (X1) }\end{array}$ & $4,7 \pm 0,45$ & 9,63 & $4,22 \pm 0,27$ & 6,36 \\
\hline $\begin{array}{l}\text { Keliling } \\
\text { Tarsometatarsus (X2) }\end{array}$ & $2,3 \pm 0,18$ & 8,13 & $2,2 \pm 0,18$ & 8,5 \\
\hline Panjang tibia(X3) & $7,74 \pm 0,47$ & 6,10 & $7,1 \pm 0,18$ & 2,63 \\
\hline Panjang femur(X4) & $4,4 \pm 0,43$ & 9,77 & $4,22 \pm 0,45$ & 10,65 \\
\hline Panjang sayap(X5) & $13,96 \pm 0,37$ & 2,66 & $14,02 \pm 0,36$ & 2,59 \\
\hline $\begin{array}{l}\text { Panjang } \\
\text { jari ketiga(X6) }\end{array}$ & $5,42 \pm 0,29$ & 5,44 & $5,02 \pm 0,35$ & 7,09 \\
\hline Panjang maxilla(X7) & $4,16 \pm 0,19$ & 4,68 & $3,98 \pm 0,23$ & 5,92 \\
\hline
\end{tabular}

Ket : $\overline{\mathrm{X}}=$ Rataan, $\mathrm{SD}=$ Standart devisiasi, $\mathrm{KK}=$ Koefisien Keragaman, $\mathrm{n}=$ Jumlah sampel

Tabel 4 menunjukkan koefisien keragaman pada organ tubuh luar belibis batu antara belibis batu jantan dan belibis batu betina memiliki kesamaan. Koefisien keragaman tertinggi terdapat pada panjang femur. Pada belibis batu jantan yaitu, 9,77\% dan belibis batu betina yaitu, 10,65\%, sedangkan koefisien keragaman terendah terdapat bpada panjang sayap. Pada belibis batu jantan yaitu, 2,66\%, dan belibis kembang betina 2,59\%. Kesamaan ini menunjukkan perbedaan organ tubuh luar tidak sepenuhnya dapat menjadi patokan dalam menunjukkan perbedaan belibis jantan dan betina pada spesies belibis batu.

Panjang organ pencernaaan belibis batu memiliki perbedaan dengan organ luarnya.Panjang organ dalam dapat memperlihatkan beberapa perbedaan antara belibis jantan dan belibis betina.Ini dapat dilihat dari Tabel 5. Pengukuran pada belibis batu jantan dan belibis batu betina sebanyak masing-masing 5 ekor memperlihatkan panjang paruh pada belibis batu jantan dan belibis batu betina menunjukkan kesamaan koefisien keragaman tertinggi dalam pengukuran panjang organ pencernaan belibis batu jantan menunjukkan koefisien keragaman yaitu, 5,89\%, dan belibis batu betina yaitu, 5,76\%, tetapi koefisien terendah pada belibis batu jantan dan betina tidak menunjukkan kesamaan. Koefisien keragaman terndah belibis batu jantan terdapat pada usus besar yaitu, 2,07\%, sedangkan pada belibis batu betina koefisien keragaman terendah terdapat pada panjang usus kecil yaitu, $3,26 \%$. 
Panjang organ pencernaaan belibis batu memiliki perbedaan dengan organ luarnya.Panjang organ dalam dapat memperlihatkan beberapa perbedaan antara belibis jantan dan belibis betina.Ini dapat dilihat dari Tabel 5. Pengukuran pada belibis batu jantan dan belibis batu betina sebanyak masing-masing 5 ekor memperlihatkan panjang paruh pada belibis batu jantan dan belibis batu betina menunjukkan kesamaan koefisien keragaman tertinggi dalam pengukuran panjang organ pencernaan belibis batu jantan menunjukkan koefisien keragaman yaitu 5,89\%, dan belibis batu betina yaitu, 5,76\%, tetapi koefisien terendah pada belibis batu jantan dan betina tidak menunjukkan kesamaan.

Tabel 5. Ukuran panjang organ saluran pencernaan belibis batu $(\mathrm{cm})$

\begin{tabular}{|c|c|c|c|c|}
\hline \multirow[t]{2}{*}{ Variabel } & \multicolumn{2}{|c|}{$\begin{array}{c}\text { Jantan } \\
(\mathrm{n}=5 \text { ekor })\end{array}$} & \multicolumn{2}{|c|}{$\begin{array}{l}\quad \text { Betina } \\
(n=5\end{array}$} \\
\hline & $\begin{array}{c}\text { Hasil } \\
\text { pengukuran }\end{array}$ & KK $(\%)$ & $\begin{array}{c}\text { Hasil } \\
\text { pengukuran }\end{array}$ & KK (\%) \\
\hline Paruh $\left(\mathrm{X}_{1}\right)$ & $3,78 \pm 0,22$ & 5,89 & $3,77 \pm 0,21$ & 5,76 \\
\hline $\begin{array}{l}\text { Panjang Oesophagus } \\
\left(\mathrm{X}_{2}\right)\end{array}$ & $4,53 \pm 0,18$ & 3,98 & $4,16 \pm 0,2$ & 5,03 \\
\hline $\begin{array}{l}\text { Panjang } \\
\text { Proventrikulus }\left(\mathrm{X}_{3}\right)\end{array}$ & $4,9 \pm 0,21$ & 4,38 & $4,43 \pm 0,23$ & 5,32 \\
\hline $\begin{array}{l}\text { Panjang } \\
\text { Usus Kecil }\left(\mathrm{X}_{4}\right)\end{array}$ & $26,87 \pm 1,13$ & 4,22 & $25,58 \pm 0,83$ & 3,26 \\
\hline $\begin{array}{l}\text { Panjang } \\
\text { Usus Besar }\left(\mathrm{X}_{5}\right)\end{array}$ & $7,6 \pm 0,15$ & 2,07 & $7,25 \pm 0,33$ & 4,62 \\
\hline
\end{tabular}

Ket $: \overline{\mathrm{X}}=$ Rataan, SD = Standart devisiasi, KK = Koefisien Keragaman, $\mathrm{n}=$ Jumlah sampel

Koefisien keragaman terndah belibis batu jantan terdapat pada usus besar yaitu, 2,07\%, sedangkan pada belibis batu betina koefisien keragaman terendah terdapat pada panjang usus kecil yaitu, 3,26\%. Perbedaaan berat organ dalam saluran pencernaan memiliki beberapa penentu. Pengukuran berat organ dalam saluran pencernaan pada belibis batu dapat dilihat dari Tabel 6.

Berat organ pencernaan pada belibis batu jantan dan belibis batu betina pada Tabel 6 memperlihatkan perbedaan.Koefisien keragaman tertinggi pada belibis batu jantan terdapat pada berat usus kecil yaitu, 5,31\%, sedangkan koefisien keragaman tertinggi pada belibis batu betina terdapat pada berat tembolok yaitu,9,45\%. Koefisien keragaman tertinggi ini menunjukkan keragaman yang tinggi pada berat organ pencernaan pada belibis batu. Koefisien terendah pada belibis batu jantan terdapat pada berat kloaka yaitu, 0,76\%, sedangkan pada belibis batu betina terdapat pada berat hati yaitu, 2,08. 
Tabel 6. Ukuran berat organ saluran pencernaan belibis batu $(\mathrm{g})$

\begin{tabular}{lcccc}
\hline \multicolumn{1}{c}{ Variabel } & $\begin{array}{c}\text { Jantan } \\
(\mathrm{n}=5 \text { ekor })\end{array}$ & \multicolumn{3}{c}{$\begin{array}{c}\text { Betina } \\
(\mathrm{n}=5 \text { ekor })\end{array}$} \\
\cline { 2 - 5 } & $\begin{array}{c}\text { Hasil } \\
\text { pengukuran }\end{array}$ & KK $(\%)$ & $\begin{array}{c}\text { Hasil } \\
\text { pengukuran }\end{array}$ & KK (\%) \\
\hline Berat Oesophagus $\left(\mathrm{X}_{1}\right)$ & $1,55 \pm 0,02$ & 1,67 & $1,35 \pm 0,06$ & 5,03 \\
Berat Tembolok $\left(\mathrm{X}_{2}\right)$ & $0,25 \pm 0,01$ & 3,74 & $0,22 \pm 0,02$ & 9,45 \\
Berat Proventrikulus $\left(\mathrm{X}_{3}\right)$ & $0,89 \pm 0,03$ & 3,58 & $0,73 \pm 0,06$ & 9,04 \\
Berat Ventrikulus $\left(\mathrm{X}_{4}\right)$ & $18,74 \pm 0,32$ & 1,52 & $17,85 \pm 0,44$ & 2,49 \\
Berat Usus Kecil $\left(\mathrm{X}_{5}\right)$ & $4,48 \pm 0,23$ & 5,31 & $4,33 \pm 0,25$ & 5,77 \\
Berat Usus Besar $\left(\mathrm{X}_{6}\right)$ & $3,23 \pm 0,12$ & 3,87 & $2,93 \pm 0,23$ & 7,99 \\
Berat Kloaka $\left(\mathrm{X}_{7}\right)$ & $1,84 \pm 0,01$ & 0,76 & $1,8 \pm 0,03$ & 2,12 \\
Berat Hati $\left(\mathrm{X}_{8}\right)$ & $7,10 \pm 0,13$ & 1,83 & $0,94 \pm 0,14$ & 2,08 \\
\hline
\end{tabular}

Ket $: \overline{\mathrm{X}}=$ Rataan, $\mathrm{SD}=$ Standart devisiasi, $\mathrm{KK}=$ Koefisien Keragaman, $\mathrm{n}=$ Jumlah sampel

Tabel 7. Rekapitulasi hasil data penciri ukuran dan penciri bentuk pada belibis kembang

\begin{tabular}{lcc}
\hline Ukuran dan Bentuk & Penciri Ukuran & Penciri Bentuk \\
& $\mathrm{X} \pm \mathrm{SD}$ & $\mathrm{X} \pm \mathrm{SD}$ \\
\hline Organ Luar & Panjang sayap & Panjang jari ketiga \\
& $15,81 \pm 0,29$ & $5,82 \pm 0,26$ \\
Panjang Organ Pencernaan(cm) & Panjang usus kecil & Panjang usus besar \\
& $28,03 \pm 1,14$ & $7,78 \pm 0,27$ \\
& & \\
Berat Organ & Berat hati & Berat hati \\
Pencernaan $(\mathrm{g})$ & $10,39 \pm 0,48$ & $10,39 \pm 0,48$ \\
\hline
\end{tabular}

Tabel 8. Rekapitulasi hasil data penciri utama ukuran dan penciri bentuk pada Belibis batu

\begin{tabular}{lcc}
\hline Ukuran dan Bentuk & Penciri Ukuran & Penciri Bentuk \\
& $\mathrm{X} \pm \mathrm{SD}$ & $\mathrm{X} \pm \mathrm{SD}$ \\
\hline Organ Luar & Panjang tibia & Panjang sayap \\
& $7,1 \pm 0,18$ & $14,02 \pm 0,36$ \\
Panjang Organ Dalam $(\mathrm{cm})$ & Panjang usus kecil & Panjang proventrikulus \\
& $7,25 \pm 1,14$ & $7,78 \pm 0,27$ \\
Berat Organ Dalam $(\mathrm{g})$ & Berat ventrikulus & Berat usus kecil \\
& $18,30 \pm 0,58$ & $4,41 \pm 0,24$ \\
& & \\
\hline
\end{tabular}




\section{Rekapitulasi Hasil Penelitian}

Data di olah dengan menggunakan program SPSS 18.Pengukuran organ tubuh bagian luar dilakukan kepada 20 ekor belibis kembang (Dendrocygna arcuata) dan belibis batu (Dendrocygna arcuata) yaitu masing-masing 10 ekor belibis jantan dan 10 ekor belibis betina.Beberapa bagian tubuh bagian luar menunjukkan hasil yang berbeda tidak jauh dari perbandingan antara belibis kembang jantan dan belibis kembangbetina.

Berdasarkan Tabel 7 dan Tabel 8 rekapitulasi, dapat dilihat ukuran dan bentuk tubuh pada belibis kembang dan belibis batu mempunyai korelasi yang positif antara kedua jenis belibis ini.Pengukuran organ luar, panjang dan berat organ pencernaan dapat diukur maka akan diperoleh hasil rekapitulasi penciri utama ukuran dan bentuk yang dapat dilihat dari tabel di bawah ini.

\section{Sifat kualitatif warna bulu pada belibis kembang (Dendrocygna arcuata) dan belibis batu (Dendrocygna javanica)}

Sampel belibis kembang dan belibis batu yang telah diamati memperlihatkan perbedaan variasi warna bulu. Warna bulu yang dapat dilihat antara belibis kembang dan belibis batu banyak memiliki kesamaan warna bulu. Berdasarkan Gambar 1 dan 2 menunjukkan warna bulu yang seragam antara belibis jantan dan betina dari kedua sampel penelitian, dari masing-masing 5 ekor belibis jantan 5 ekor belibis betina. Perbedaan antara kedua jenis sampel belibis ini bisa di bandingkan dengan melihat ketebalan garis pada bagian bulu atas kepala sampai leher, bagian dada, pola lingkaran di bagian atas punggung dan bagian ujung tubuh sampai bawah ekor.

Beberapa bagian bulu pada kedua jenis belibis ini ada kesamaan yang membuat kesulitan membedakan masing-masing belibis kesamaan pola warna pada bagian paruh, bagian sayap, bagian punggung dan kaki. Perbedaan pola warna bulu ini telah disusun pada Tabel 9 .

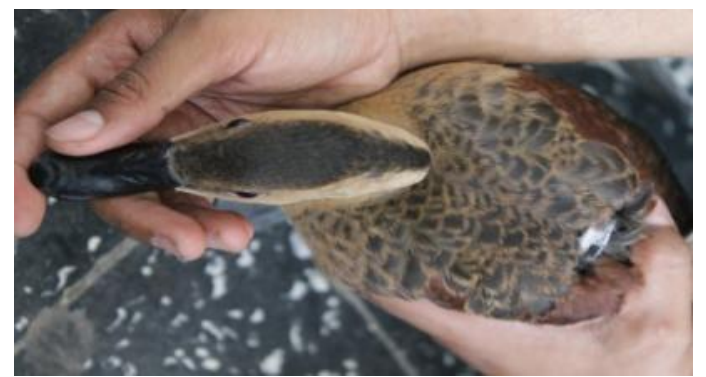

Gambar 1. Belibis kembang

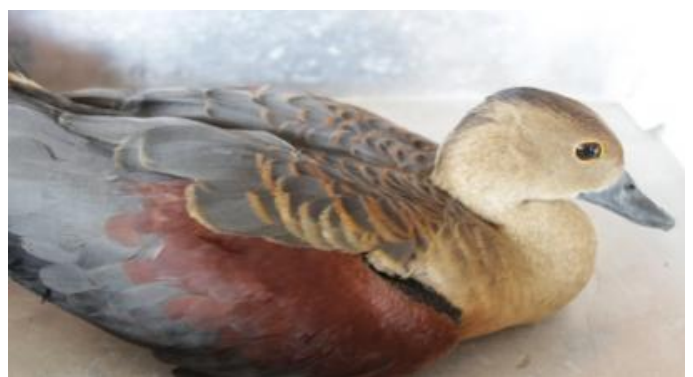

Gambar 2. Belibis batu 
Tabel 9. Karakteristik sifat-sifat kualitatif warna bulu

\begin{tabular}{|c|c|c|c|c|c|}
\hline \multirow[t]{2}{*}{ Sifat kualitatif } & \multicolumn{2}{|c|}{ Belibis kembang } & \multicolumn{2}{|c|}{ Belibis batu } & \multirow{2}{*}{$\begin{array}{l}\text { Frekuensi } \\
\text { relative } \\
(\%)\end{array}$} \\
\hline & Jantan & Betina & Jantan & Betina & \\
\hline \multicolumn{6}{|l|}{ Bagian kepala: } \\
\hline $\begin{array}{l}\text { - coklat bergaris hitam tebal } \\
\text { - coklat bergaris hitam tipis }\end{array}$ & 5 & 5 & - & - & 100 \\
\hline (pucat) & - & - & 5 & 5 & 100 \\
\hline \multicolumn{6}{|l|}{ Bagian paruh } \\
\hline - hitam & 5 & 5 & 5 & 5 & 100 \\
\hline \multicolumn{6}{|l|}{ Bagian leher : } \\
\hline - coklat bergaris hitam & 5 & 5 & - & - & 100 \\
\hline - coklat & & & 5 & 5 & 100 \\
\hline \multicolumn{6}{|l|}{ Bagian dada : } \\
\hline - coklat terang & 5 & 5 & - & - & 100 \\
\hline - merah maroon & - & - & 5 & 5 & 100 \\
\hline \multicolumn{6}{|l|}{ Bagian punggung : } \\
\hline $\begin{array}{l}\text { - berbintik hitam garis lingkar } \\
\text { kuning jumlah lebih banyak } \\
\text { - berbintik hitam garis lingkar }\end{array}$ & - & - & 5 & 5 & 100 \\
\hline $\begin{array}{l}\text { kuning jumlah lebih sedikit } \\
\text { Bagian sayap : }\end{array}$ & 5 & 5 & - & - & 100 \\
\hline $\begin{array}{l}\text { - hitam dan merah maroon } \\
\text { Bagian ekor : }\end{array}$ & 5 & 5 & 5 & 5 & 100 \\
\hline - hitam dan putih & 5 & 5 & - & - & 100 \\
\hline - hitam dan merah maroon & - & - & 5 & 5 & 100 \\
\hline Bagian kaki : & & & & & \\
\hline - hitam & 5 & 5 & 5 & 5 & 100 \\
\hline
\end{tabular}

Berdasarkan Tabel 9 di atas dari 20 ekor belibis yang terdiri dari : 5 ekor belibis kembang jantan, 5 ekor belibis kembang betina, 5 ekor belibis batu jantan dan 5 ekor belibis batu betina dapat dilihat perbedaan dan persamaan warna bulu dari kedua jenis belibis ini.

\section{Kerumunan Data}

Hasil olahan data pada Analisa Komponen Utama (AKU) dapat dilihat pada diagram kerumunan.Bentuk sebaran data morfologi dan morfometri pada burung belibis kembang dan belibis batu yang telah diolah dapat dilihat pada Gambar 3 dibawah ini.

Pada Gambar 3 grafik kerumunan organ luar menunjukkan perbedaan antara kerumunan organ luar kedua jenis belibis.Pada kelompok kerumunan di kanan bawah grafik menunjukkan ukuran yang lebih besar pada penciri utama belibis kembang sedangkan pada kelompok di kiri atas grafik menunjukan bentuk yang lebih besar pada penciri utama belibis 
batu.Skor ukuran tubuh belibis kembang lebih besar dibandingkan skor ukuran tubuh belibis batu sedangkan skor bentuk tubuh belibis batu lebih besar dibandingkan belibis kembang.

Sumbu X merupakan ukuran tubuh dan sumbu Y merupakan skor bentuk tubuh.Ukuran dan bentuk tubuh pada gambar diperoleh berdasarkan persamaan komponen utama yang diturunkan berdasarkan masing-masing sampel belibis yang diamati.

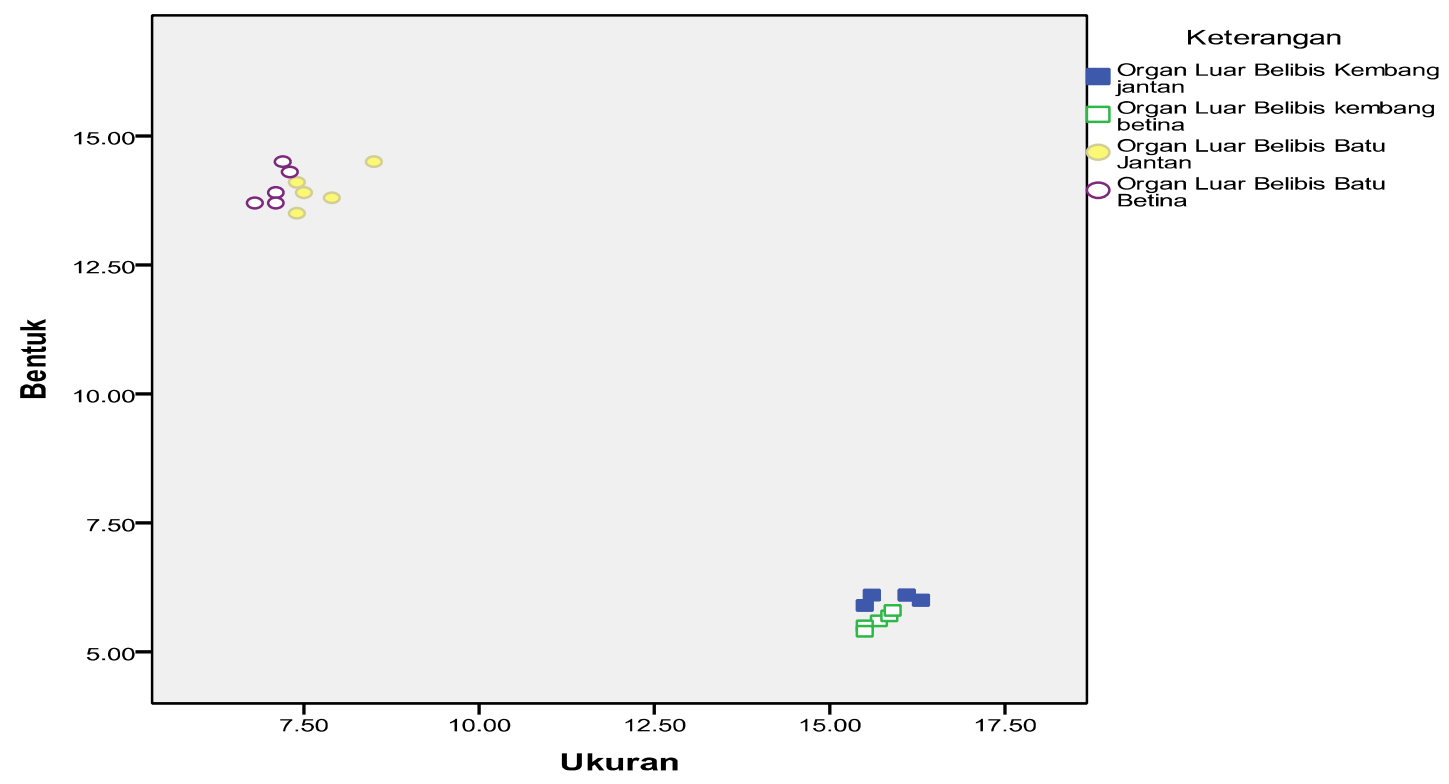

Gambar 3. Grafik Kerumunan(sebaran) organ luar belibis kembang dan belibis batu

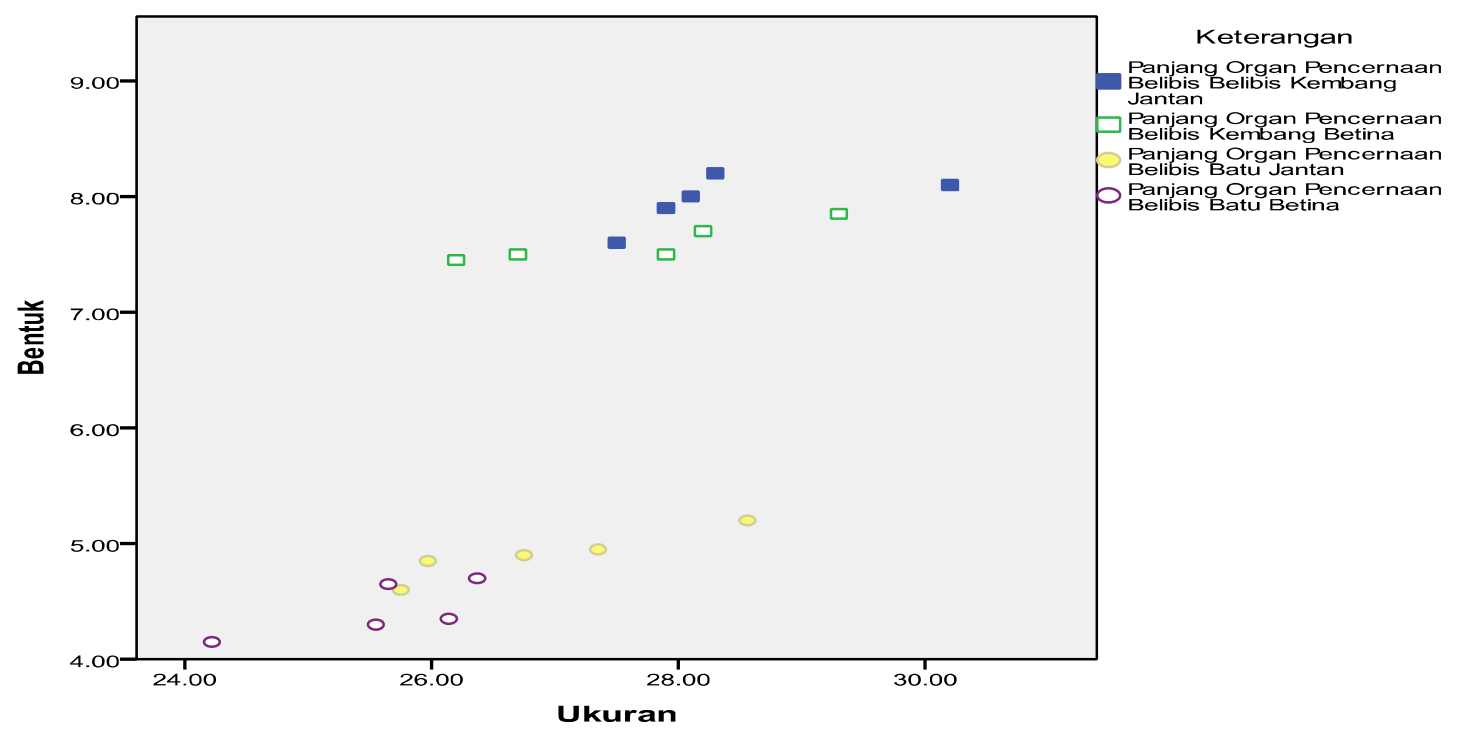

Gambar 4. Grafik kerumunan(sebaran) panjangorgan pencernaanbelibis kembang dan belibis batu. 


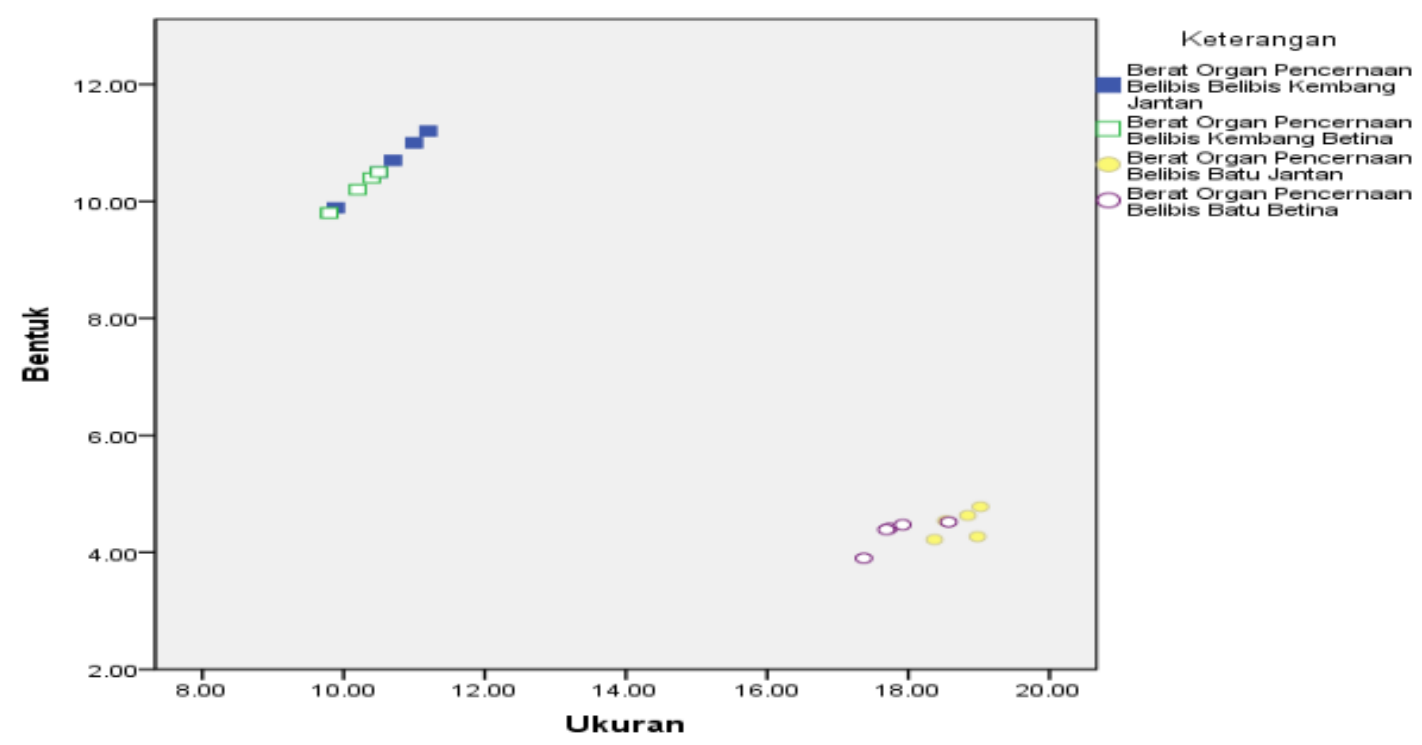

Gambar 5. Grafik kerumunan (sebaran) data berat organ pencernaan belibis kembang dan belibis batu.

Panjang organ pencernaan kedua jenis belibis dapat dilihat dalam bentuk scatter plot yang diolah dengan SPSS 18 pada Gambar 4 grafik kerumunan panjang. Dapat dilihat pada Gambar 5 yaitu grafik kerumunan berat organ dalam kedua jenis belibis.Skor ukuran dan bentuk tubuh pada berat organ pencernaan belibis kembang lebih besar dibandingkan belibis batu ini dapat dilihat dari berat hidup belibis kembang yang jauh lebih berat dibandingkan belibis batu.

Berdasarkan ketiga gambar grafik yang ada disimpulkan bahwa pada belibis kembang memiliki Skor bentuk tubuh yang jauh lebih besar dibandingkan belibis batu ini di tunjukkan dengan berat hidup yang ada pada kedua jenis belibis. Pada grafik organ luar belibis batu menunjukkan skor bentuk tubuh yang lebih besar dibandingkan belibis kembang tetapi pada grafik panjang dan berat organ dalam skor bentuk tubuh didominasi belibis kembang.

\section{KESIMPULAN}

Penciri utama ukuran dan penciri bentuk menunjukkan morfologi dan morfometri organ pencernaan belibis kembang yang lebih besar di bandingkan dengan belibis batu. Belibis kembang memiliki garis hitam tebal dari atas kepala sampai leher dan warna bulu putih yang tebal pada bagian tubuh belakang sampai ekor. Belibis batu memiliki warna merah maroon mencolok pada bulu bagian dada. 


\section{DAFTAR PUSTAKA}

Arif Darmawan . 2011. Merintis jalan Berbisnis Belibis. http://epetani.deptan.go.id/budidaya/merintis-jalan-berbisnis-belibis. Diakses Maret 2012.

Frandson.R.D., 1992. Anatomi dan Fisiologi Ternak. UGM Press. Yogyakarta.

Gasperz, V., 1992. Teknik Analisis dalam Penelitian Percobaan. Jilid 2. Tarsito,Bandung.

Hardjosubroto,W., 1994.Aplikasi Pemuliabiakan di Lapangan. Gramedia Widiasarana Indonesia. Jakarta.

Nishida, T., Y,Hayashi., Hashiguci, and S.S, Mansjoer., 1982. Distribution and Identitification of Jungle Fowl inIndonesia. The Origin and Phylogeny of Indonesia Native Livestock.

Noor, R.R., 1996. Genetika Ternak. Penebar Swadaya.Jakarta.

Parera, J.D., 1991. Pengantar Ilmu Linguistik Umum Seri B Bidang Morfologi, Ende Flores : Nusa Indah

Semarang Bird Web (SBW)., 2009. Belibis Batu. http://www.bio.undip.ac.id/sbw/spesies/sp_belibis_batu.htm. [diakses pada tanggal 23 Maret 2009].

Srigandono, B., 1986. Ilmu Unggas Air. UGM Press, Yogyakarta.

Tzeng, T.D., C.S, Chiu., S.Y, Yeh., 2000. Morphometric Variation in Redspot Prawn (Metapenaeopsis barbata) in Defferent Geographick Waters of Taiwan. Institute of Oceanography, National Taiwan University.Taypei 106, Taiwan ROC.

Wikipedia., 2007. Belibis kembang.http://wikipedia.co.id/03/2007/burung_belibis_kembang/ [diakses pada tanggal 27 april 2009]. 